\title{
ВПЛИВ ВІМ-ТЕХНОЛОГІЙ НА РОЗРОБКУ ТЕХНОЛОГІЧНИХ КАРТ БУДІВЕЛЬНИХ ПРОЦЕСІВ
}

\section{THE INFLUENCE OF BIM-TECHNOLOGIES ON THE DEVELOPMENT OF TECHNOLOGICAL MAPS OF CONSTRUCTION PROCESSES}

\author{
Мудрий І.Б. к.т.н., доцент каф. БВ (Національний університет \\ “Львівська політехніка", м. Львів) \\ Mudryj I.B., Ph.D., senior lecturer (National University of Lviv \\ Polytechnic, Lviv)
}

Запропоновано основні вимоги до формування організаційно-технологічної документації з врахуванням технології інформаційного моделювання, з розробкою нормативної бази та відповідним підвищення кваліфікації інженерно-технічних прачівників, з можливістю їх навчання. Визначено причини низького рівня застосування інформаційних технологій для розробки технологічних карт будівельних прочесів та їх зальний вплив на створення інформаційних моделей.

The main requirements for the formation of organizational and technological documentation with regard to infor-mation modeling technology are proposed. The reasons for the low level of application of information technologies for the development of technological maps of construction processes and their general impact on the creation of information models are identified. Works to expand the information modeling technology, taking into account the technological and organizational solutions of construction, will cause the emergence of new requirements for the development of technological maps: the construction master plan should be developed based on a threedimensional model of the construction site and other factors that affect construction; dynamics of changes in dangerous areas of the construction site when changing the number of floors (installation horizon) and height characteristics of the machines; the location of warehouse sites (their areas), the direction of movement of construction equipment and workers, depending on the accepted organizational and technological scheme of construction at a certain time; establishing of dynamic restrictions on the performance of works, the location of divisions (zones of work) in space and time (especially when organizing construction in the zones of existing enterprises); reconciliation of necessary engineering resources according to the stages of construction.

Ключові слова: технологічна карта, проект виконання робіт; проект організації будівництва; технологія інформаційного моделювання; організаційнотехнологічна документація.

Keywords: technological map; work production project; construction organization project; information modeling technology; organizational and technological documentation. 
Технологічні карти (ТК) є складовою частиною проекту виконання робіт (ПВР) [1], а процес їх розробки (особливо нетипової ТК) трудомісткий та затратний за часом, оскільки така задача часто $\epsilon$ багатоваріантною. Спростити процес розробки ТК, 3 підвищенням їх якості та скороченням термінів, можливо на основі використання сучасних технологій інформаційного моделювання (ТIM) [2]. Однак основний організаційно-технологічний документ (ДБН А.3.1-5:2016) не визначає та не регламентує порядок формування інформаційних моделей для технологічної документації.

Аналіз вимог [2, 3] до формування загальних інформаційних моделей показує, що такі рішення для технологічних карт повинні грунтуватись на трьох основних принципах:

1. Систематизація та структуризація цільової задачі зведення;

2. Наявність розвиненої нормативної бази, яка повинна мати нормативний та довідково-методичний апарат, необхідний для формування вхідних та вихідних даних;

3. Автоматизація рішень конкретних задач, які розділяються на блоки: календарний план виконання робі; технологія та організація виконання робіт; охорона праці; техніка безпеки та ін.

Використання інформаційних технологій, зокрема комплексів ВIM (Building Information Modelling), у практиці будівництва, дозволяє на [3]: 10\% знизити вартість проектної документації; 7-15\% скоротити термін реалізації проектів; 3\% підвищити точність кошторисної документації; $80 \%$ скоротити час розробки проектної документації; $30 \%$ зменшити відходи та брак будівельного виробництва.

Безпосередньо для технологічних карт впровадження технологій інформаційного моделювання - складна задача, оскільки їі розробка повинна грунтуватися на принципах «зворотнього зв'язку» - від розробників технологічних карт до виконавців проекту організації будівництва (ПОБ). Відповідно, чим складніший об'єкт, тим більше складових (ТК) буде вимагати загальна організаційно-технологічна документація. Це створює умови для розвитку ринку, коли зовнішні спеціалізовані сервіси (компанії) будуть надавати свої масштабовані інформаційні ресурси для загальної інформаційної моделі проекту [4]. Створення таких масштабованих технологічних карт - трудомісткий процес, однак перспективний для субпідрядних компаній, в плані просування своїх послуг. Такий процес буде вимагати формування реалістичних образів моделей виконуваних видів робіт, використання баз даних (машин, механізмів, інструментів, обладнання та ін.) [5].

На практиці слід відзначити низький рівень впровадження інформаційного моделювання в частину організаційно-технологічної 
документації (ОТД), на відміну від конструктивних та інженерних (мережі) частин проекту. Основними причинами такого стану є:

- відсутність затвердженої державної нормативної бази, яка б регламентувала роботу над технологією інформаційного моделювання в цілому і в частині ОТД зокрема [6];

- розірваність між різними етапами розробки організаційнотехнологічної документації;

- обмеженість ринку фахівців, направлених на розробку інформаційних моделей для технологій зведення.

Для більшості компаній основна мета практичного використання ВІМ-технології полягає у підвищені якості проектної документації (уникнення помилок) та використання інформаційного моделювання в розрахункових модулях та візуалізації. Створення технологічних карт, як складової частини ПВР, $є$ задачею підрядників, для яких виконання їх в комплексах ВIM є ускладнене через відсутність в штаті відповідних фахівців. Залучення зовнішніх виконавців не завжди виправдане через недостатність технологічного досвіду, неврахування технічних можливостей компаній, наявності та стану відповідного обладнання та ін.

Метою роботи $\epsilon$ розглянути стан впровадження технологій інформаційного моделювання в практику розробки технологічних карт для процесів виконання робіт.

\section{Виклад основного матеріалу}

Перехід до ВIM не завжди призводить до значного прискорення процесу проектування (рис. 1), радше - до перерозподілу пріоритетів: зменшується частка зусиль, що витрачаються на рутинні операції, в той час як вивільнені ресурси можуть бути направлені на більш інтелектуальну та технологічну діяльність, зосереджуючись на якості проектних рішень, інформаційних моделей, аналітичних вишукувань, управлінні проектом тощо [6].

Додаткове введення у такий розподіл варіантності розробки організаційно-технологічної документації, збільшить зусилля на проектування, але визначення оптимальних організаційно-технологічних рішень на цьому етапі дозволить знизити загальні затрати на зведення до $40 \%$ [7].

На вітчизняному ринку для створення інформаційних моделей в основному використовуються програмні комплекси Autodesk Revit, Tekla Structures, Allplan, Bentley Building Designer (переважно для розділів проекту АР; КБ; ОВ). Для ОТД використовують комплекси для роботи 3 окремими частинами ПОБ та ПВР - «СПДС СТРОЙПЛОЩАДКА», Microsoft Project; PlanWIZARD; Spider Project; GanttProject та ін. Ці програми значно спрощують роботу і над ТК, дозволяючи: створювати та виводити ряд розрахункових табличних звітів, календарних графіків, відомостей робіт, ресурсів; здійснити підбір та оцінку рівня застосування 
комплектів механізації, крім того спрощують роботу в частині графічних даних - дають можливість побудувати на вивести зони впливу машин, обмеження на роботу, динаміку зміни зон обмеження, напрямків переміщення вантажів та ін.

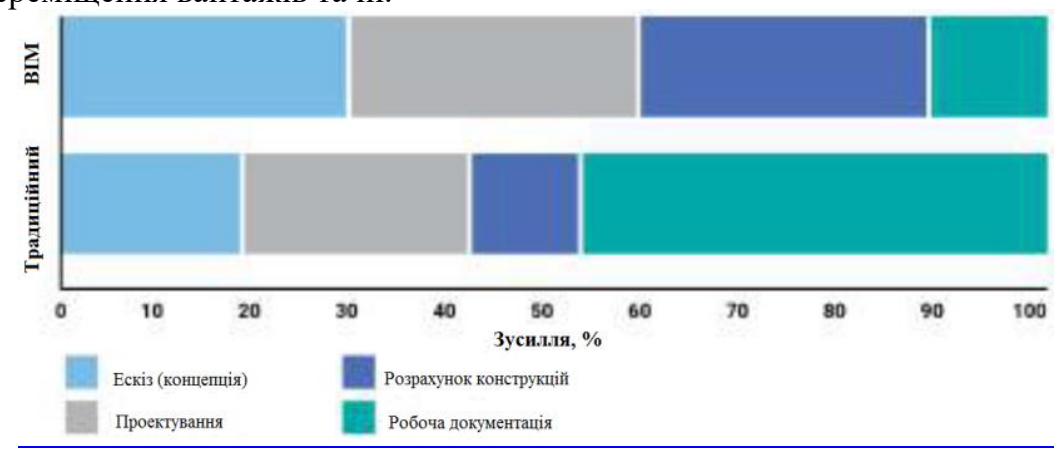

Рис. 1. Орієнтовний перерозподіл зусиль у процесі проектування [6]

Але повністю автоматизувати процес розробки ТК на сучасному етапі складно, через обмежену можливість уніфікації прийнятих рішень на загальному рівні. Сьогодні існують автоматизовані рішення на рівні окремих процесів, наприклад, розкладка опалубки, розташування блочних елементів риштувань, підбір технологічних параметрів машин та ін. Такі системи, як правило, є закриті, розроблені під певний ресурс, i їх складно використати для загально-майданчикової інформаційної моделі. Поряд 3 комплексами, які дозволяють здійснювати підбір варіантів ефективних комплектів механізації $[8,9]$, відсутні програми, що можуть поєднувати в IM роботи декількох машин у спільній зоні впливу. При роботі з двома та більше машинами виникає необхідність застосування окремих неінтегрованих підпрограм для пошуку раціонального варіанту зведення. Разом 3 тим, на ринку спостерігається розширення банку технологічних даних (моделей) будівельної техніки, обладнання, пристосувань, інструменту тощо.

Задача створення інформаційних моделей для ТК, крім раціонального прийняття технологічного порядку зведення, буде вимагати врахування великого масиву даних: фактичного стану майданчика; умови вхідного та приймального контролю; фактичний стан машини, технологічного оснащення та інструменту; умов з техніки безпеки та охорони праці; вимог 3 охорони навколишнього середовища; вимог щодо транспортування, складування та зберігання; пожежної безпеки та ін. Фактично інформаційна модель для створення технологічних карт повинна поєднувати три групи даних: 1) вхідні (проектні рішення); 2) фактичні умови та обмеження; 3 ) нормативні вимоги. 
Відповідно до створення інформаційної моделі на рівні ТК, будуть висуватися ряд вимог щодо іiї змісту:

- інформаційна модель будівельного майданчика (з поділом на ділянки (деталізацією) та обсягами робіт між підрядниками з врахуванням напрямку розвитку виробництва, можливих шляхів руху техніки, робітників, постачання). Технологічна схема зони виконання робіт повинна бути розроблена на основі фактичної тривимірної моделі майданчика та навколишньої території, із зонами обмеження, які впливають на зведення. Обов'язковим є ув'язка з календарним графіком для відображення поточної зміни ситуації на ділянці.

- інформаційна модель технологічних процесів - календарний графік виконання. Такий графік повинен бути створений у вигляді динамічної моделі, яка коригує роботу технологічних машин відповідно до планових та фактичних часових параметрів виконання робіт;

- моделювання окремих робочих операцій, 3 урахуванням необхідного додаткового обладнання та обмежень на роботу. Крім того, важливим буде рівень проробки (деталізації) інформаційної моделі (кількість включених операцій, робочих переміщень, атрибутивна та просторово-геометрична інформація тощо). Модель повинна містити дані, які враховують умови виконання робіт - температурний та часовий режим (зимовий-літній період, денний-нічний час, стан технологічного обладнання та ін.);

- рішення з організації контролю виконання операцій, з варіантами можливого автоматизованого контролю;

- відомість (журнал), яка дозволяє відслідковувати поточний стан виконання процесів (БМР) на об'єкті та їх контролю.

Висновки. Розширення технологій інформаційного моделювання 3 врахуванням технологічних та організаційних рішень зведення створить нові вимоги до розробки технологічних карт:

- розробка ТК повинна грунтуватися на принципах «зворотнього зв'язку» технологічна карта - проект виконання робіт - проект організації будівництва;

- створення масштабованих типових технологічних карт на основі BIM технологій, з можливістю оперативної адаптації під проектні рішення та умови будівельного майданчика;

- створення відкритих модулів (які дозволяють розширення) підпрограм;

- застосування окремих відкритих модулів відкриє умови для варіантної проробки проектних рішень, що дозволить виконувати пошук оптимальних варіантів зведення. 


\section{Список використаної літератури}

1. ДБН А.3.1-5:2016 Організація будівельного виробництва. К.: Украхбудінформ, 2016. $46 \mathrm{c.}$

2. Талапов В.В. Технология ВIM: Суть и особенности внедрения информационного моделирования зданий. М.: ДМК Пресс, 2015. 410 с

3. Трофимов Л.А., Трофимов В.В, Информационное моделирование и инжиниринговые системы организации управления как основа инновационного развития строительной отрасли. Весник Омского университета. Серия «Экономика». 2016. №3 С.77-82.

4. Мудрий І. Б. Перспективи використання технології інформаційного моделювання при розробці проектів організації будівництва // Науковий вісник будівництва. - 2020. - Т. 100, № 2. - С. 132-137.

5. Колесников Е.Б., Синенко С.А. Технологии виртуальной реальности в отображении строительного генерального плана при возведении объекта. Промышленное и гражданское строительство. 2012. № 11. С. 44-46.

6. Лист № 62-01-659 Київ, МОНУ № 1-9-197 Концепція ВIМ - Будівельно Інформаційного Моделювання в Україні. Додаток

7. Гусаков А.А. Системотехника / А.А. Гусаков, В.О. Чулков, Н.И. Ильин М.: Новое тысячилетие, 2002, - 768 с

8. Мудрий І.Б. Порядок та реалізація принципів формування ефективного комплекту стрілових кранів. Збірник наукових праць «Управління розвитком складних систем». Київ, 2017. № 30. С. 156-162.

9. Іванейко І.Д., Мудрий І.Б., Олексів Ю.М. Формування та ефективність технологічних конструктивних рішень стрічкових фундаментів зведених із-за меж котловану. //Сучасні технології та методи розрахунків у будівництві. Зб. наук. праць. - Луцьк: ЛНТУ, 2015.-вип.3.- С. 79-92.

\section{References}

1. DBN A. 3.1-5: 2016. Organization of construction production. 2016.

2. Talapov V.V. BIM technology: The essence and features of building information modeling implementation. 2015. 410 p.

3. Trofymov L.A., Trofymov V.V. Information modeling and engineering systems of management organization as the basis of innovative development of the construction industry. Series "Economy". 2016. No. 3. pp. 77-82.

4. Mudryi I. B. Perspektyvy vykorystannia tekhnolohii informatsiinoho modeliuvannia pry rozrobtsi proektiv orhanizatsii budivnytstva // Naukovyi visnyk budivnytstva. - 2020. - T. 100, № 2. - P. 132-137

5. Kolesnikov E.B., Sinenko S.A. Virtual reality technologies in displaying the construction mas-ter plan during the construction of an object. 2012. №11. pp. 44-46.

6. Letter no. 62-01-659 Kyiv, MONU No.1-9-197 Concept of BIM - Construction Information Modeling in Ukraine. Appendix.

7. Gusakov A.A., Chulkov V.O., Ilyin N.I. Systems Engineering. 2002.

8. Mudryi I.B. Procedure and implementation of the principles of forming an effective set of jib cranes. Collection of scientific papers "Managing the development of complex systems". 2007. No. 30. pp. 156-162.

9. Ivaneiko I.D., Mudryi I.B., Oleksiv Y.M. Formuvannia ta efektyvnist tekhnolohichnykh konstruktyvnykh rishen strichkovykh fundamentiv zvedenykh iz-za mezh kotlovanu. //Suchasni tekhnolohii ta metody rozrakhunkiv u budivnytstvi. $\mathrm{Zb}$. nauk. prats. -Lutsk: LNTU, 2015.- Issue 3.- P. 79-92. 